\title{
CHECKPOST CHESS
}

\section{Exploring the relationship between insurgents and illicit trade}

\author{
Shalaka Thakur \\ Vehicles pass through our land, it is our duty to receive tax from them. \\ KNO (non-state armed group) member ${ }^{1}$
}

\section{Introduction}

When you visit the Government of India Land Ports Authority website and check the amount of trade at the official Indo-Myanmar border crossing 'Moreh,' the total import and export presented $^{2}$ is INR 0 per year. The truckloads of products - from everyday electronics and medicines to areca nuts and cigarettes - that you see crossing at this buzzing border paint a different picture. When you speak to the traders doing business across this border, their estimate for licit goods is INR 10-15 crores (EUR 1.4-1.7 million) per day. Much of the trade that happens across this border, therefore, is 'informal trade,' done without import/export tariffs, commonly understood as smuggling. Illicit goods like drugs carve out a separate space for themselves. Security forces at the border on the Indian side estimate an approximate INR 4,000 crores (EUR 463 million) worth of heroin and meth entering Manipur through Moreh each year.

This border crossing is also dotted with various non-state armed groups, state security forces, and other state actors. This chapter seeks to explain the role that non-state armed groups play in shaping the smuggling economy. ${ }^{3}$ While non-state armed groups and smugglers are often instinctively considered natural allies, given the covert nature of their functioning, as evidence from this case shows, their role in the smuggling economy is far more complex than commonly understood. Furthermore, it is often intrinsically tied to their relationship with the state and state actors. By exploring the relationships non-state armed groups have with the state and traders/smugglers, ${ }^{4}$ this chapter seeks to elucidate how the three create and mould the informal cross-border economy.

Most literature around insurgents and smuggling has focused on the role smuggling plays in rebel finance and the role of informal economies in sustaining rebel groups. However, the reverse - the role that non-state armed groups play in the wider smuggling economy - has not been explored as much. Predominantly ensconced in literature on 'war economies' (see Berdal 
and Malone 2000, Keen 1998, Nordstrom 2004), works arguing 'greed' as a key driver of conflict (Collier and Hoeffler 2001), and viewing war economies as a 'malignant form' of economic activity (Ballentine and Sherman 2003) put the role of insurgents in economically viable areas like cross-border trade in a primarily exploitative light. Other accounts speak to the ambiguities of war economies and the livelihoods they create, and the communities that come to depend on them (Duffield 2001, Nordstrom 2004). Moving beyond the lens of war economies, Weigand (2020) finds that the role non-state armed groups play in the smuggling economy depend on and are tempered by the amount of territorial control they enjoy and the extent to which they depend on public legitimacy, offering more nuance to the rebel-smuggler link. As van Schendel and Abraham (2005) postulate, law and crime both emerge from historical and ongoing struggle over legitimacy. Understanding the role that insurgents play, beyond being merely economically driven actors, is hence imperative to understanding their role in the smuggling economy.

Many borderlands, and certainly this one, are a space of overlapping and competing state and non-state authorities, blurring the lines of what the 'state' is in terms of both monopolisation of violence and questions of legitimacy. They are thus, as scholars have argued, places where state authority may be contested or at times even entirely supplanted (van Schendel 2005). Moving beyond the Weberian idea of the state is therefore an imperative step to understanding the functioning of the smuggling economy. It is useful then, to take what Hagmann and Peclard $(2010,46)$ would call a 'more grounded approach to statehood whose starting point is empirical and not judicial.' The rebel governance and wartime orders literature (see e.g., Arjona 2016; Mampilly 2011; Staniland 2012) looks at rebels as actors with an interest in and ability to control and govern territory, beyond simply engaging in violence against the state, and has much to contribute in this regard. The role of non-state armed groups in this economy, conversely, also allows for a more nuanced and comprehensive understanding of authority and regulation in informal cross-border trade. This trade itself can be viewed as a function of hybrid governance resulting from the interactions of state and non-state actors (Titeca and Flynn 2014), including armed groups, and economic informality viewed, not as a lack of state regulation, but rather as alternative forms of regulation, operating below and beyond the framework of the state (Meagher 2011). Furthermore, this kind of informal regulation may at least in part be based on socially accepted understanding (Raeymaekers 2010).

Drawing on these insights, this chapter sets out to further our understanding of the role of non-state armed groups in informal cross-border trade through the case of Moreh at the IndoMyanmar border. To explore some of the ways in which non-state armed groups shape the smuggling economy, it firstly investigates the micro-dynamics of the way fees and access of goods and vehicles across the border are negotiated by such groups. This section of the chapter also delves into the logics of taxes, as expressed by them, levied by non-state armed groups. The variations in manner of involvement speak to questions of authority, with professed logics of their involvement in the smuggling economy seemingly state-like in their ambition. This section also illustrates that, contrary to distinct zones of control, with territories clearly demarcated between state and rebel control, there is an intertwining of the state and non-state actors, who operate in the same space and time.

The next section looks into how non-state armed groups incentivise smuggling. On the one hand, it finds that by levying informal fees on traders, non-state armed groups incentivise them to skirt state-imposed tariffs. Traders can often avoid state taxes, but not those of non-state authorities, which speaks to dimensions of how control and authority are exercised in the borderlands. It also finds that rules and taxes levied at the border by non-state armed groups 
create informal barriers to entry, allowing only certain types of traders and smugglers, who are organised and rich enough to deal with these groups, access to some cross-border trade.

The last section in this chapter looks at the effect of ceasefires and other agreements geared towards reducing violence in the smuggling economy. It finds that groups in agreements with the state play a much bigger and more systematic role in the smuggling economy, and that this, in turn, perpetuates corruption on the side of the state. Creating a type of political order which lies somewhere between coexistence and collusion and occasional confrontation, these agreements, while playing the much-needed role of reducing active fighting and conflict, also perpetuate systems of methodical exploitation and entrench vested interests.

\section{Mapping Moreh: micro-dynamics of informal cross-border trade}

Slip kaatne se hi gaadi ja sakti hain

(without their (non-state armed group's) receipt, your truck cannot move). ${ }^{5}$

- Trader, Moreh

In some ways, the relationship that informal traders have with non-state armed groups and with the state are strikingly similar. Many traders interviewed in Moreh do not find the involvement and taxes taken informally from the non-state armed groups any more or less unacceptable than the tariffs levied formally by the state, or the bribes taken informally by state actors. It is amounts and process of involvement that concerns traders, not the legality of the actor involved. For some smugglers dealing in illicit goods, they avoid detection by non-state armed groups and state security with equal determination. For others, the non-state armed groups are akin to 'business partners' who create conditions that are favourable to them and their business. This section will touch upon all three of these relationships.

\section{The actors}

The non-state armed groups found in this border region ${ }^{6}$ can be divided broadly into three ethnic groups: the Kuki groups like the KNA (Kuki National Army) and UKLF (United Kuki Liberation Front) whose area of influence is (AoI) Moreh town; the Naga group NSCN-IM (Nationalist Socialist Council of Nagaland-Isak Muivah); and various Manipur valley-based groups, who are currently based on the Burmese side of the border, while making the occasional appearance in Moreh. All groups stand on a platform of secession or greater autonomy. The state actors found here are customs and sales tax officers, police, IRB (Indian Reserve Battalion), paramilitary (called Assam Rifles), and the army. The presence of the insurgent groups, in part believed to be covertly supported by China, ${ }^{7}$ explains the presence of various Indian security forces. All these actors play a direct or indirect role in the smuggling economy. While some actively get involved in trading of different goods, usually, taxes and bribes in the form of cash or cuts from the shipment are taken by all the non-state armed groups and many of the state actors. Contrary to how the smuggling economy is often envisioned, the areas of state and non-state control are not clearly divided or demarcated; rather, they are all operating in the same space.

While some traders belong to the Meitei communities that are originally from Manipur, many big traders based in Moreh are 'Mayangs' or 'outsiders, ${ }^{8}$ mostly from other parts of India. Though from different communities and dealing in different goods, they speak of 'Mayang unity' while dealing with non-state armed groups. The trader community has formed a 
'Chamber of Commerce' in Moreh that not only has to deal with the state, but also negotiates with non-state armed groups. The yearly lump sums to be paid are negotiated with different groups by the whole community so as to get beneficial rates from the non-state armed groups. Their relationship with the non-state armed groups is to a great extent similar to the one with state actors, when paying fees and taxes. In addition to this, the traders also pay a house tax to some Kuki non-state armed groups. ${ }^{9}$ As many of the traders do not belong to ethnicities that are originally from the region, and whose non-state armed groups function in this region, friction between the trader communities and non-state armed groups sparks up from time to time. However, the degree of violence has gone down over the past couple of decades. A trader who has been in Moreh since the 1980s described 'They were very violent, they would threaten. Now it has been systemised. ${ }^{, 10}$ Despite the reduction in violence that long-term traders spoke of, paying the non-state armed groups is not optional.

\section{Informal taxes and unseen roads}

Paying non-state armed groups in this region is something that every big trader crossing the border must do. The payments are made in different forms. Some are fixed yearly costs paid as lump sums to different groups in the form of 'godown tax' or 'entry tax' usually ranging between 5000 and 10,000 euros per group per year. In addition, vehicles carrying the goods are taxed along the road to and from the border crossing. Receipts are given by different non-state armed groups. While some have their organisation's name on the receipt, others issue receipts under the names of non-existent transport associations. More recently, receipts have started being issued in the form of text messages.

On average, when crossing from Moreh to Imphal, the capital of Manipur a mere $107 \mathrm{~km}$ away, traders pay informal fees at least nine checkpoints on an average ride, as a part of the border crossing process into the main city. A truck carrying cigarettes or betel nuts, for example, would be taxed approximately INR 10000 (around EUR 110) per journey by non-state armed groups. In addition, there are various payoffs the traders have to make to state actors along the way, being stopped at three police checkposts, two customs posts, and occasionally one army post. They pay small bribes, usually less than EUR 10 per stop, although this varies depending on the shipment and its size. Traders at the border put the average of the informal taxes they pay to both state (in the form of bribes) and non-state armed groups at $20 \%$ of the value of their shipment, a substantial amount of it attributed to non-state armed groups.

Some goods, particularly illicit ones (teak, drugs, exotic wildlife) are often transported on parallel make-shift roads in the jungle that have been created expressly with the intention of skirting the authorities. In these cases too, they are skirting all authorities - state and non-state equally, rather than simply avoiding detection by state authorities while actively colluding with insurgents to avoid detection. For example, a teak smuggler explained that he takes other routes, even though they are much slower and inconvenient, as he finds "fewer UGs (underground groups, local term for non-state armed groups" after "under ground groups" within the brackets) ${ }^{11}$ and fewer police' along these routes. ${ }^{12}$

Some non-state armed groups play an active role in smuggling and cross-border trade. For example, the NSCN-IM budget shows 'cement,' 'betel nuts' and 'trade in Moreh' as sources of income, ${ }^{13}$ which indicate a more active role in informal cross-border trade. For the most part, however, when it comes to non-state armed groups in the 'informal trade' or illegal smuggling, their involvement is mostly confined to taxation of goods crossing the border. Traders' relationships with state actors is quite similar when it comes to the payment of these fees. As one trader put it, 'We can't just blame the UGs - if they take 10 rupees, government (Indian state) 
will take $20^{\prime}{ }^{14}$ Traders also accuse the state of making legal trade extremely difficult, and wanting to keep their own informal checkpoints, where they collect bribes on crossing the border - a steady source of income.

\section{Drugs and drawing lines}

The role of non-state armed groups in the drug economy is a surprising one. According to sources within Moreh and the state security forces on the ground, while a few non-state armed groups in Moreh tax drugs arriving from Myanmar, this is in no way the norm.

Heroin and World is Yours (WY) tablets (methamphetamine mixed with caffeine) come in from Myanmar, while ephiderenes and amphetamines go across from India to Myanmar (Shivananda 2011). These ingredients are then often used to convert opium into heroin, known locally as 'number 4.' At the Assam Rifles checkpoints, cars and people are thoroughly checked. Drug addiction rates in Manipur are very high, with more than $10 \%$ of the general population being opioid users (GoI report 2019). According to the Indian Army webpage this drug corridor is an easy source of income for insurgents who collaborate with criminal gangs to smuggle drugs across the border' (Indian Army webpage 2019). According to Indian security forces on the field though, non-state armed group involvement is limited. The non-state armed groups that are involved in the movement of drugs do not play a major role and also do not treat drug trafficking as a major source of income for their group. Furthermore, despite the lucrative nature of the drug business at this border, many non-state armed groups do not take a cut on drugs at all, on the basis of ideology, a view claimed not only by them, but reiterated by traders and locals in Moreh. It is often politicians and state security forces that are linked to large movements of drugs, according to traders and media reports. ${ }^{15}$ The non-state armed groups of communities (like the Kuki community), that are known traditionally to grow opium are also described by the Indian state security forces as playing a very small role in the drug economy, mostly as runners and small fry. During a meeting I attended of an NGO which has been working with drug addicts and protesting the rise of the drug economy, many of them believed that the drug trade had grown considerably since the valley-based non-state armed groups had been driven out by the Indian security forces. Although it is difficult to triangulate this claim, the perception of these NGOs and civilians that the non-state armed groups keep the drug trade in check is an interesting and unintuitive one.

Another example of the tempering effects legitimacy is seen to have on the type of trade non-state armed groups get involved in can be seen with human trafficking. Despite India's being a lucrative market and a major destination for human smugglers, and despite the very porous nature of the border, non-state armed groups at this border are largely not involved in human trafficking, as per accounts of the local community and traders in Moreh. In 2018, when the trafficking of underage girls was taken up by some businessmen in Moreh, it was condemned by the local community, including the non-state armed groups. ${ }^{16}$ The traffickers were, according to locals, outsiders - not a part of the usual trader community or tribal population of Moreh - and were driven out as they were seen as a threat to the 'social fabric' of Moreh.

\section{Narratives of non-state armed groups}

A member of the KNA, a major player in the Moreh informal economy, explained why his group took cuts from vehicles crossing the border. He frames this sort of involvement as their 'right towards their mission' as they are fighting for their land and their people. He framed their involvement in cross-border trade as an articulation of their presence, beyond just financing of 
their group. This authority is backed by evidence from constituents in the group's area of influence. On occasions when the state security forces take action against collections on goods entering and leaving Moreh, they are often faced with violent protests by locals, indicating a degree of legitimacy of the KNA in the area. Similarly, as a minister from the non-state armed group the NSCN-IM proclaimed, 'They can never stop the NSCN from collecting taxes, they cannot stop this contribution to the movement. ${ }^{17}$ While his quote was in reference to all taxes taken by the group in all their areas of influence, the cuts taken from cross-border trade form a substantial amount. ${ }^{18,}$

\section{Making of the smuggler: how non-state armed groups incentivise smuggling}

'They (referring to a non-state armed group) will call me and say "Eat well. Today is your last dinner".

$$
\text { - Smuggler, Moreh }{ }^{19}
$$

Although it is the state that, through legislation, makes an act of trade smuggling, within these established legal bounds the presence of non-state actors often pushes traders dealing in licit goods into trading their products across the border illegally, thereby incentivising smuggling. The presence of non-state armed groups provides a new set of authorities to deal with and pay. Paying multiple sets authorities is unfeasible for many traders, and when having to choose whom to pay, it is often easier (and safer) for traders to avoid paying the state authorities rather than non-state armed groups, thereby leading to more traders dealing in legal goods to choose to avoid state-imposed tariffs and resort to smuggling.

In line with this, non-state armed groups also create systems of informal regulations and barriers to entry on the movement of certain goods, in some cases incentivising certain types of people and smugglers over others. In some cases therefore, the presence of non-state armed groups helps certain smugglers and traders capture a larger share of the market by creating barriers to entry, not unlike what the state does.

\section{Incentivising smuggling}

Peter Andreas (2009) postulates that if tariffs are high, smugglers are incentivised to smuggle legal commodities trying to evade these tariffs. The presence of non-state armed groups, in a similar vein, makes the (informal) $\operatorname{taxes}^{20}$ to be paid by traders high, even if the state is not levying them. At some crossings, where non-state armed groups are the only authority present, they might replace the state and determine the tariff prices. At other places, like in Moreh, where they function alongside the state, it changes the traders' calculation of whether and how much to pay each authority in question.

High state-imposed tariffs are a reason traders give for avoiding formal, legal trade. However, they blame, in equal part, the presence of non-state armed groups and the less avoidable taxes that they charge. Many cite the difficulties of paying non-state armed groups as the reason they cannot afford to pay state tariffs in addition to these informal tariffs. In many cases, if it were just the state taxes they had to pay, they claim they would. However, knowing that they have to pay taxes to various non-state armed groups, often under the threat of violence, makes paying both unfeasible. Since non-payment to non-state armed groups is a dangerous option, having far harsher implications, they instead opt for not paying the official state tariffs, bribing state actors whom they meet along the way instead. 
The cycle of increased informal trade at Moreh can thus be attributed to the tariffs by both the state and non-state armed groups. The state often kicks it off with high tariffs. For example, at the Indo-Myanmar border in Moreh, there is an 'Integrated Check Post (ICP).' Equipped with state-of-the-art infrastructure, multiple lanes for trucks to ply and sophisticated screening devices, it is usually, nevertheless, empty. At the time of my last visit in early 2020, it was absolutely desolate. When I met the officer in charge and complimented him on the scale and grandeur of the checkpost, he sheepishly commented on how it would be even nicer if anyone used it. ${ }^{21} \mathrm{He}$ is referring to how most traders avoid it on account of the official tariffs they would have to pay there. Moving a few hundred meters away from the slick, lonely ICP concrete roads to the blurry dirt paths, trade is abuzz.

Trucks carrying goods from Myanmar stop on the Myanmar side. The goods are then carried as headloads or piled on to motorcycles and carried to trucks on the Indian side, where they are piled onto Indian trucks. Police sit languidly by, watching the trucks load. Their lookout is for drugs and arms, and the movement of the electronics, garments, cigarettes, toys, cement and medicine before them now is not of much interest. They understand, like everyone else here, that this trade is important, and its technically being 'informal' is little reason to stop it. The trucks on the Indian side, having entirely avoided the ICP, then embark on a journey dotted with stops by the state and non-state armed groups.

In some cases, the state tariffs are considered too high to pay, irrespective of non-state armed group taxation and fees. Multiple traders mentioned the example about the remarkably high tariffs on importing betel nuts (40\%) under India's new 'Normal Trade' policy from 2015, up from a previous concessionary rate of just $5 \%$. One of the most traded items across the border, traders are now unable to pay this high tariff, and betel nut is traded informally, with reports showing that smuggling surged in the aftermath of the change in these tariffs (see, for example Ambedkar et al. 2019). While customs offices can sometimes be seen overflowing with seized betel nuts, some customs officers in their interviews also admit the counterproductive effect of this tariff on formal trade and the difficulties traders face because of it. Paying state-imposed tariffs can avert the bribes traders pay to the 'uniformed' (state) collectors along the way, but the latter option often proves to be more economical and expedient. Multiple traders complained of how they had tried going down the legal route a couple of times, and how it was made extremely difficult for them. As one trader grumbled 'Instead of telling us (to do formal trade), why don't they change their rules? ${ }^{22}$ However, state officers and customs officials speak to the entrenched vested interests traders have in operating outside the legal system, arguing that they would be unwilling to pay even if official tariffs were reasonable. ${ }^{23}$

As illustrated in the section above, paying non-state armed groups in this region is something that every big trader crossing the border must do. These are costs that traders cannot avoid or forgo, under the threat of violence, and must factor into their expenses. Paying the formal tariff in addition would make no business sense, explained traders. Non-state armed groups on the Indo-Myanmar border thus play no small role in encouraging traders to forgo the payment to the state. They make traders who have been working in these regions 'smugglers' from the Indian state's point of view. As far as the non-state armed groups are concerned though, this is their land, their area of control, and dues have been paid.

\section{Barriers to entry and informal regulation}

The presence of non-state armed groups can determine the level of organisation of the smugglers. According to Andreas, the level of organisation in smuggling economies varies considerably, depending especially on a state's 'tough' enforcement practices at a certain border 
(ibid., p. 20). Non-state armed groups in Moreh and their enforcement of taxes also plays a role in pressurising traders into more organised structures. It creates a sort of barrier-to-entry which only seasoned traders and smugglers are able to cross.

As one teak smuggler candidly declared 'I consider them (the UGs) as business partners. ${ }^{24}$ In his line of work, he explained running a successful business meant keeping others out of it and the non-state armed groups served as partners in making this happen. Since he has been in this industry for a while, he is able to negotiate with the groups and pay their charges. In exchange, the higher tariffs the groups would charge newcomers dissuades competition, giving him a near monopoly.

\section{Peace deal/piece meal: how ceasefires and suspension of operations play a role in the smuggling economy}

Earlier they (referring to a non-state armed group) used to be scared, now as they have an agreement, they take openly. Now they've just set up a gate (to collect money). ${ }^{25}$

- Trader, Moreh

De-escalation of violence through ceasefires and other peace deals comes at a price and with the non-state armed groups along the Indo-Myanmar border areas, this price often takes the form of offering a larger piece of the pie in the smuggling economy. Smuggling becomes a larger, more organised part of the ceasefire economy for both non-state armed groups as well as state actors, playing an arguably larger role during halfway peace than it did during the peak of conflict.

Certain features of ceasefires and suspension of operations deals (SoO) at Moreh lead to a degree of impunity from state actions against non-state armed groups, as the trade-off for the state would be a return to active fighting. This leads to increased territorial control, as their territory is no longer actively contested militarily by the Indian state, although they may continue to fight other groups over territory. As territorial control sets the outer limits to which they can involve themselves in the smuggling economy, agreements with the state enhance the possibility of non-state armed groups involving themselves in the smuggling economy in a larger and more systematic way. This, in turn, cements their presence in the area, which entrenches a large presence of state security forces in the region, with quite a substantial slice of the smuggling arranged for themselves. Agreements can also be seen as a form of 'external legitimacy,' or recognition by the Indian state. Non-state armed groups who are (tacitly) allowed to operate may therefore alter their dependence on internal legitimacy from their own constituents, thereby changing the calculus of what sorts of smuggling a group might get involved in.

\section{Restructuring the calculus of territorial control and internal legitimacy}

The role that non-state armed groups play in the smuggling economy depends heavily on public legitimacy and territorial control (see Weigand 2020). The sort of state-insurgent relationship can affect directly how much territory a non-state armed group is able to control, as well as the extent to which internal legitimacy factors into its role in informal trade. Confrontation, coexistence or collusion of/with the state is what, to a large extent, determines how much territory a group controls, as well as how dependent they remain on internal legitimacy in their decision making. 
While legitimacy and accountability might regulate what types of smuggled goods non-state armed groups get involved in, it is territorial control that sets the external limits to where and how they are able to get involved in smuggling. The extent of territory controlled determines the amount and method of collection and how regularised the taxation is. Non-state armed groups that control territory would be able to set up collection checkpoints, where they take a specific cut based on certain criteria, like vehicle and shipment size and type. Apart from this, they also collect fixed yearly contributions from regular traders. Groups that do not control territory would have a more ad hoc manner of collection, taking as much as they can, when they can. While traders lose a far greater percentage in taxes to the non-state armed groups controlling territory, they can account for it based on regularisation and predictability. Traders interviewed in Moreh were able to map out where they had to pay and an approximation of how much for the non-state armed groups that control territory. From the groups that do not control territory, the monetary pinch is considerably less, but the ad hoc nature of collection makes it harder to prepare for. A trader may or may not have to pay a cut to a non-state armed group not controlling territory, but when he does it is difficult to predict the amount and when it will happen.

To illustrate, let us do a case comparison of non-state armed groups in varying relationships with the state. You see two kinds of groups - the ones who are still actively fighting with/ hiding from the state, and with whom the Indian state currently has no form of a peace deal, are Meitei groups, from the Manipur valley. Groups with which the state is currently in ceasefire or suspension of operations are the NSCN-IM and the Kuki groups. Valley-based groups previously had an allocated spot that they operated out of on the Myanmar side of the border. Multiple traders recalled being called in for meetings to determine rates to be paid, and the valley-based non-state armed groups were considered heavyweights even among the crowded non-state armed group space in this border region. After heavy securitisation/military interventions over the past decade, including a couple of joint operations with the Myanmar army to oust valley-based groups, the usual post they used to function out of remains empty and unused. Constantly being on the run from security forces has pushed them into hiding, and the valleybased groups who now no longer control territory, and their role in the smuggling economy on this border has been reduced to that of an ad-hoc collector. According to traders, the collection from these groups has been reduced to close to nothing ${ }^{26}$ over the last two years. The removal of this once big player in the smuggling economy due to militarisation has, however, not drastically reduced the 'cut' of non-state armed groups in the smuggling economy. Despite this, they make ad-hoc payment demands, particularly in the form of the big sums to be paid by smugglers yearly.

Let's compare this type of involvement with that of non-state armed groups that are in some sort of agreement with the state. As per the rules of the ceasefire, which the state has with the Naga group the NSCN-IM, they are not allowed to engage in 'extortion.' Similarly, as per the SoO, which the state has with various Kuki groups, the non-state armed groups are to remain in their camps and suspend all operations (as the name would suggest), including taxation of goods from across the border. However, these arrangements, rather than forcing non-state armed groups to toe this line, tend to offer a degree of tacit permission by the state, who would prefer this buy-out to a resurgence of violence. The NSCN-IM is a Naga group that has been in ceasefire with the Indian state since 1997. The 1990s saw turf wars for the control of Moreh. While the Kukis won this turf war and Moreh is considered their area of influence, traders doing business in Moreh need to factor in the NSCN-IM and negotiate the yearly rate they pay the group on goods coming from across the border. In addition, they have a collection point a few kilometres from Moreh. The ceasefire has increased the income of the NSCN-IM, 


\section{Checkpost chess}

a sizeable amount of which comes through their cuts and involvement in cross-border trade. For example, the trade of betel nuts is one of the sources of income for the military wing of the NSCN-IM, the Naga army, adding about INR 1275000 (EUR 146,500) ${ }^{27}$ to their revenue in the year 2019-2020. The taxes and fees taken by the group are stated as an income source in their budget. Apart from the betel nuts and other major goods, 'Moreh market, transport of goods to and fro' is another entry that can be found in the 'sources of income' part of the NSCN-IM budget. The actual sum collected probably differs substantially from the numbers in the budget, much like the fees taken by state actors in 'informal' ways would not show up in import duties or customs reports of the state. The NSCN-IM also takes onus for many taxes they levy on the goods going through their area of influence/territory. When the IM takes a cut from a shipment, the name of the organisation, as well as a signing authority is on the receipt they issue. The ceasefire further allows them this symbolism, as the tradeoff for taking sustained action against this taxation would tip the precarious balance of the ceasefire. In a way, through the claiming of the taxes they are charging on goods coming from and going into Myanmar, they differentiate themselves from other armed actors who take cuts without attaching their name to it, creating the impression of a proper signing authority that levy taxes on shipments moving through their area.

The role of the state, in many cases, does not remain that of turning a blind eye to the cuts taken by non-state armed groups in order to maintain peace, but a far more active role in this smuggling economy themselves. The murky borderland is in in fact a much-desired posting with rumours of police heads paying up to an equivalent of 1 crore rupees (EUR 113,000) for the postings. In Moreh, non-state armed group collection points that I observed were a stone's throw away from police and security forces along the same route.

David Brenner's chapter, (following this one) compellingly describes the case of economic pacification, geared towards breaking 'rebel-smuggler nexus,' can increase violence, conflict and insecurity. This is not only because economic interventions in contexts of conflict can shift the incentives of warring factions in unforeseen ways. In the context of Moreh, you see how halfway peace is bought by incentivising non-state armed groups to get a larger part of the smuggling economy, while simultaneously incentivising an informal state-smuggler nexus. While reduction of violence and eventual peace is an imperative goal to move towards, as one trader complained in reference to the consequences of the suspension of operations arrangements, 'Agreements with government should not be a mandate for harassing public. ${ }^{28}$

\section{Conclusion}

Dono ka phayda hain, magar public ka phayda nahi hain. ${ }^{29}$

(They both (non-state armed groups and state actors) profit, but the people lose.) - Trader, Moreh

The relationship among traders, non-state armed groups and the state is a complicated one, and in its many permutations and combinations, is an important factor in shaping the economy of informal and illicit cross-border trade. This chapter attempted to throw some light on this relationship.

The findings in this chapter challenge the idea that smuggling occurs in rebel-controlled borderlands, beyond the purview of the state. On exploring the micro-dynamics of the smuggling economy, it finds that the role of non-state armed groups are in fact often inextricably interwoven with state actors. It demonstrates how non-state armed groups play a 
large role in incentivising smuggling in a space that they often share with state actors, while at the same time creating parallel informal barriers-to-entry for different goods and types of smugglers. They are not alone though, with state legislation and state actors also encouraging the informal trading of goods across the border. The presence of non-state armed groups leads to the presence of many state security forces in this region, increasing the number of actors in the movement of goods across the border, and determining the calculus of what informal arrangements must be made or what fees must be paid. Finally, the chapter shows that a larger piece of the smuggling economy for non-state armed groups and state actors is often the price for (relative) peace. Traders consider agreements between the state and non-state actors contributing factors to more systematic and larger cuts taken by both. The fear-infested environment of constant conflict was, contrary to popular belief, less fertile a field for smuggling.

The case of Moreh presents useful insights into the role of non-state armed groups, and how their entangled relation with state actors shapes the smuggling economy. These findings speak to an undeniable need to pay closer attention to non-state armed groups while studying the smuggling economy and to the value of using smuggling as a lens through which to understand non-state armed group governance and authority in the borderlands.

\section{Notes}

1 Interview, April 2021.

2 In Indian Rupees (INR) crores.

3 Based on research conducted in the border town of Moreh, in the state of Manipur at the IndoMyanmar border 2019-2021. Interviews were conducted primarily with traders, who deal with both state and non-state armed groups to negotiate cross-border trade and also with members of non-state armed groups, customs officers and state security forces. Alongside this, observations on how crossborder trade takes place were conducted. This choice of methodology takes an empirical rather than legal approach to the actualities of mapping informal trade and governance of border regions.

4 I use the word 'trader' instead of 'smuggler' in many cases as this is term used by the traders themselves and even the customs officials and state security forces in the region for people who trade in licit goods even if they are not paying state tariffs. Interviewees across the board would draw a clear distinction between what they consider 'informal trade' - the trade of electronics, food items, cigarettes, betel and areca nuts, clothes, toys and other licit goods traded - and 'smuggling,' a term that they reserve for drugs, exotic wildlife products, people and arms. Trader, customs officers and security forces, while describing trade in Moreh would use the categories 'formal trade,' 'informal trade' and 'illegal smuggling.' These different understandings of trade do not fit into the neat categories of external observers. In fact, he need for 'informal trade' version of this smuggling economy is considered as necessary, even by actors within the state apparatus. In the state of Manipur alone, more than 50,000 people out of the 2.8 million population are estimated to depend on the smuggling economy for their livelihood, $90 \%$ of it attributed to the crossing in Moreh (see Mahadevan 2020).

5 Interview, trader, Moreh January 2020.

6 My findings for this chapter are primarily based on the Indian side of the border, and the different actors traders would encounter at the Moreh-Tamu border.

7 Based on telephonic interviews with army officers in October 2020, also see https://www.efsas.org/ commentaries/differences-between-nscn-and-indian-government-raises-suspicions-of-a-chinese-hand/ https://www.business-standard.com/article/current-affairs/china-s-weapon-supply-to-myanmarterrorists-re-ignites-insurgency-fears-120072500118_1.html.

8 Term used in Manipur for people who are not Meitei, Kuki or Naga but from mainland India.

9 According to interviewees in the community, during the turf wars between Naga and Kuki non-state armed groups, both organised on the basis of tribe and ethnicity, when both groups tried to recruit the then large Tamil trading community to join their non-state armed groups as they had numbers and sizeable resources, an offer which they declined.

10 Interview, trader, Moreh January 2020.

11 term used locally for non-state armed groups. 


\section{Checkpost chess}

12 Interview, Manipur February 2021.

13 Based on NSCN-IM budget for the year 2019-2020.

14 Telephonic interview, trader, August 2020.

15 According to local interviewees in Moreh and for example: https://indianexpress.com/article/northeast-india/manipur/imphal-district-council-chairman-arrested-along-with-drugs-worth-over-27crore-5226048/; https://timesofindia.indiatimes.com/india/Army-officer-five-others-held-withdrugs-worth-Rs-24-cr-in-Manipur/articleshow/18667037.cms.

16 Interview, Moreh, January 2020.

17 Interview, Manipur November 2019.

18 based on the NSCN-IM budget for 2019-20.

19 Interview, Imphal, February 2021.

20 I use the term 'tax' as it the term used by the non-state armed groups and by the traders and often times 'illegal tax' as referred to by state authorities.

21 Interview, Moreh January 2020.

22 Interview, trader, Moreh January 2020.

23 Interview, state official, Manipur August 2020.

24 Interview, Manipur February 2021.

25 Interview, trader Moreh January 2020.

26 Interview, trader, Moreh January 2020.

27 Budget for the NSCN-IM 2019-20.

28 Telephonic Interview, Trader, August 2020.

29 January 2020. While in this quote he is referring to the non-state armed groups and state actors, it should be noted here that the trader community is also amongst those who profit as per local accounts in Moreh and Imphal and as can be seen in the example of the teak smuggler.

\section{References}

Andreas, P. (2009) Border Games: Policing the U.S.-Mexico Divide (2nd ed). Ithaca, NY and London: Cornell University Press.

Ambedkar, A., Agrawal, A., Rao, R., Mishra, A. K., Khandelwal, S. K. and Chadda, R. K. (2019). Magnitude of Substance Use in India. On behalf of the group of investigators for the National Survey on Extent and Pattern of Substance Use in India New Delhi: Ministry of Social Justice and Empowerment, Government of India.

Arjona, A. (2016) Rebelocracy: Social Order in the Colombian Civil War. Cambridge: Cambridge University Press.

Ballentine, K. and Sherman, J. (2003) The Political Economy of Armed Conflict. Beyond Greed and Grievance. Boulder and London: Lynne Rienner Publishers.

Berdal, M. and Malone, D. (2000) Greed and Grievance: Economic Agendas in Civil War. London: Lynne Rienner Publishers.

Collier, P. and Hoeffler, A. (2001) Greed and Grievance in Civil War. Washington DC: World Bank.

Duffield, M. (2001) Global Governance and the New Wars: The Merging of Development and Security. Zed Books.

Hagmann, T. and Péclard, D. (2010) Negotiating Statehood: Dynamics of Power and Domination in Africa. Development and Change. 41. 539-562.

Keen, D. (1998) The Economic Functions of Violence in Civil Wars. Adelphi Papers No.320. Oxford: International Institute for Strategic Studies.

Mahadevan, P. (2020) Crossing the line, GI-TOC report. https://globalinitiative.net/analysis/indiamyanmar/

Mampilly, Z. (2011) Rebel Rulers: Insurgent Governance and Civilian Life during War. Ithaca, London: Cornell University Press.

Meagher, K. (2011) Informal Economies and Urban Governance in Nigeria: Popular Empowerment or Political Exclusion?. African Studies Review. 54. 47-72. doi: 10.1353/arw.2011.0026.

Nordstrom, C. (2004) Shadows of War Violence, Power, and International Profiteering in the Twenty-First Century. London: University of California Press. 
Raeymaekers, T. (2010) Protection for Sale? War and the Transformation of Regulation on the Congo-Uganda Border. Development and Change. 41. 563-587.

Staniland, P. (2012) States, Insurgents, and Wartime Political Orders. Perspectives on Politics. 10(2). 243-264.

Shivananda, H. (2011) Nexus of Drug Trafficking and Militancy Exposed at New Delhi, IDSA Comment, https://idsa.in/idsacommentsNexusofDrugTraffickingandMilitancyExposedatNewDelhshivanandah_ 130411.

Titeca, K. and Flynn, R. (2014) "Hybrid Governance," Legitimacy, and (Il)legality in the Informal CrossBorder Trade in Panyimur, Northwest Uganda. African Studies Review. 57. 71-91. doi: 10.1017/asr.2 014.6.

Van Schendel, W. (2005) The Bengal Borderlands: Beyond State and Nation in South Asia. London: Anthem Press.

Van Schendel, W. and Abraham, I., eds. (2005) Illicit Flows and Criminal Things: States, Borders and the Other Side of Globalization. Bloomington: Indiana University Press.

Weigand, F. (2020) Conflict and Transnational Crime: Borders, Bullets and Business in Southeast Asia. Cheltenham and Northampton: Edward Elgar Publishing. 